DOI

\author{
๑А. Г. Бабінцева \\ ВДНЗ України «Буковинсъкий державний медичний університет», Чернівці
}

\title{
АНАЛІЗ ФАКТОРІВ РИЗИКУ ГОСТРОГО ПОШКОДЖЕННЯ НИРОК У ДОНОШЕНИХ НОВОНАРОДЖЕНИХ ДІТЕЙ
}

АНАЛІЗ ФАКТОРІВ РИЗИКУ ГОСТРОГО ПОШКОДЖЕННЯ НИРОК У ДОНОШЕНИХ НОВОНАРОДЖЕНИХ ДІТЕЙ. Вивчено асоціації між ймовірними факторами ризику та формуванням гострого пошкодження нирок (ГПН) у критично хворих доношених новонароджених з урахуванням особливостей стану здоров'я матерів, перебігу антенатального періоду розвитку та періоду пологів, а також клінічних проявів перинатальної патології. Проведено комплексне клінікопараклінічне обстеження 65 доношених новонароджених, у яких на тлі перинатальної патології спостерігалися порушення фрункціонального стану нирок (І група), та 30 дітей з тяжкими фрормами перинатальної патології, на тлі якої було діагностовано ГПН (II група). Встановлено, що статистично значимими пренатальними фракторами ризику формування ГПН у доношених дітей є патологія сечовидільної системи у матері (ВШ 2,68; 95 \% ДІ 1,080-6,680) та обтяжений акушерський анамнез (ВШ 2,76; 95 \% ДІ 1,129-6,764). Розвиток ГПН у дітей з тяжкою перинатальною патологією статистично значимо пов'язаний з оцінкою за шкалою Апгар менше 3 балів наприкінці п'ятої хвилини життя (ВШ 5,08; 95 \% ДІ 1,215-21,263) та клінічними ознаками поліорганного пошкодження організму: позитивним симптомом «білої плями» (ВШ 7,78; 95 \% ДІ 2,946-20,537), синдромом артеріальної гіпотензії (ВШ 4,19; 95 \% ДІ 1,67-10,516), судомним синдромом (ВШ 5,52; 95 \% ДІ 1,891-16,132), геморагічним синдромом (ВШ 5,14; 95 \% ДІ 1,548-17,09) та харчовою інтолерантністю (ВШ 3,42; 95 \% ДІ 1,347-8,497). Клінічними симптомами, які пов'язані з високою ймовірністю фрормування ГПН та випереджають суттєві зміни біохімічних маркерів, $є$ збільшення маси тіла $\geq 5$ \% від початкової на другу добу життя (ВШ 8,68; ДІ 1,675-44,912) та набряковий синдром (ВШ 3,55; $95 \%$ ДІ 1,174-10,740).

АНАЛИЗ ФАКТОРОВ РИСКА ОСТРОГО ПОВРЕЖДЕНИЯ ПОЧЕК У ДОНОШЕННЫХ НОВОРОЖДЕННЫХ ДЕТЕЙ. Изучены ассоциации между вероятными фракторами риска и формированием острого повреждения почек (ОПП) у критически больных доношенных новорожденных с учётом особенностей состояния здоровья матерей, течения антенатального периода развития и периода родов, а также клинических проявлений перинатальной патологии. Проведено комплексное клинико-параклиническое обследование 65 доношенных новорожденных, у которых на фоне перинатальной патологии наблюдались нарушения фрункционального состояния почек (I группа), и 30 детей с тяжёлыми фрормами перинатальной патологии, на фроне которых диагностировано ОПП (II группа). Установлено, что статистически значимыми пренатальными фракторами риска формирования ОПП у доношенных детей являются патология мочевыделительной системы у матери (ОШ 2,68; 95 \% ди 1,080-6,680) и отягощенный акушерский анамнез (ОШ 2,76; 95 \% ДИ 1,129-6,764). Развитие ОПП у детей с тяжёлой перинатальной патологией статистически значимо связано с оценкой по шкале Апгар меньше 3 баллов на пятой минуте жизни (ОШ 5,08; 95 \% ДИ 1,215-21,263) и клиническими признаками полиорганного повреждения организма: позитивным симптомом «белого пятна» (ОШ 7,78; 95 \% ДИ 2,946-20,537), синдромом артериальной гипотензии (ОШ 4,19; 95 \% дИ 1,67-10,516), судорожным синдромом (ОШ 5,52; 95 \% ДИ 1,891-16,132), геморрагическим синдромом (ОШ 5,14; 95 \% ДИ 1,548-17,09) и пищевой интолерантностью (ОШ 3,42; 95 \% ДИ 1,347-8,497). Клиническими симптомами, которые свидетельствуют о высокой вероятности формирования ОПП и опережают значительные изменения биохимических маркеров, являются увеличение массы тела $\geq 5$ \% от начальной на вторые сутки жизни (ОШ 8,68; ДИ 1,675-44,912) и отёчный синдром (ВШ 3,55; $95 \%$ ДІ 1,174-10,740).

ANALYSIS OF RISK FACTORS OF ACUTE KIDNEY INJURY IN FULL-TERM NEONATES. The associations between probable risk factors and formation of acute kidney injury (AKI) in critically sick full-term neonates have been studied considering health status peculiarities of mothers, the course of antenatal period of development and the period of labor as well as clinical manifestations of the perinatal pathology. A comprehensive clinical-paraclinical examination of 65 full-term neonates have been conducted. Disorders of functional kidney condition have been found in 35 infants against perinatal pathology (I group), and AKI has been diagnosed against severe forms of perinatal pathology in 30 infants (II group). Statistically significant prenatal risk factors of AKI formation in full-term infants have been found to be those connected with pathology of the maternal urinary system (OR 2.68; 95 \% Cl 1.080-6.680) and complicated obstetrical anamnesis (OR 2.76; $95 \% \mathrm{Cl} 1.129-6.764)$. The development of AKI in infants with severe perinatal pathology is statistically significant connected with the evaluation by Apgar score no less than 3 at the end of the fifth minute of life (OR 5.08; $95 \% \mathrm{Cl} 1.215-21.263$ ) and clinical signs of multisystem injuries of the body: positive symptom of «a white spot» (OR 7.78; $95 \% \mathrm{Cl}$ 2.946-20.537). arterial hypotension syndrome (OR 4.19; $95 \% \mathrm{Cl}$ 1.67-10.516). convulsive syndrome (OR $5.52 ; 95 \% \mathrm{Cl}$ 1.891-16.132). hemorrhagic syndrome (OR 5.14; $95 \% \mathrm{Cl} 1.548-17.09)$ and dietary intolerance (OR $3.42 ; 95 \% \mathrm{Cl}$ 1.347-8.497). The clinical signs connected with a high probability of AKI formation and those which lead considerable changes of biochemical markers are: gain of the body weight $\geq 5 \%$ from the initial one on the second day of life (OR 8.68; $\mathrm{Cl} 1.675-44.912)$ and swelling syndrome (OR 3.55; $95 \% \mathrm{Cl}$ 1.174-10.740).

Ключові слова: гостре пошкодження нирок, доношені новонароджені, перинатальна патологія, фрактори ризику, відношення шансів, довірчий інтервал.

Ключевые слова: острое повреждение почек, доношенные новорожденные, перинатальная патология, сракторы риска, отношение шансов, доверительный интервал.

Key words: acute kidney injury, full-term neonates, perinatal pathology, risk factors, odds ratio, confidence interval. 
ВСТУП. Гостре пошкодження нирок (ГПН) у дітей є серйозною проблемою для неонатології. Дана патологія $€$ одним із проявів поліорганної невідповідності при критичному стані новонароджених, коли декілька фрункцій організму суттєво обмежені або повністю виключені [1-3].

У сучасній неонатології діагностику ГПН у новонароджених проводили згідно з рекомендаціями міжнародної групи експертів Kidney Disease: Improving Global Outcomes 3 модисрікацією Jennifer G. Jetton та David J. Askenazi [3] Основними критеріями встановлення діагнозу $є$ збільшення рівня креатиніну сироватки крові більш ніж на 26,6 мкмоль/л протягом послідовних двох досліджень, проведених через 48 год, та/або рівень погодинного діурезу в дитини менше ніж 0,5 мл/кг/год протягом 6 год.

За даними зарубіжної літератури, частота ГПН серед новонароджених, які перебувають у відділеннях інтенсивної терапії, коливається від 8 до 22 \%, а летальність становить від 33 до 78 \% [4]. Основними групами ризику орормування ГПН у ранній неонатальний період $є$ діти, які народилися у стані асфріксії [1] та раніше фрізіологічного терміну гестації [3], а також малюки, яким проведено кардіохірургічні втручання $[5,6]$. У більшості новонароджених дітей ГПН є мультисракторним патологічним станом, який розвивається при асоціації з іншими системними ураженнями (сепсисом, гіпоксією, дихальною та серцевою недостатністю, уродженими вадами розвитку сечовидільної системи тощо) [3, 7]. В Україні відсутні дані епідеміологічних досліджень щодо розповсюдженості й чинників ризику ГПН у неонатальній групі пацієнтів, що пов'язано з відсутністю єдиних підходів до використання відповідної термінології та критеріїв діагностики [8].

Метою роботи було вивчення асоціацій між імовірними фракторами ризику та формуванням ГПН у критично хворих доношених новонароджених з урахуванням особливостей стану здоров'я матерів, перебігу антенатального періоду розвитку та періоду пологів, а також клінічних проявів основної та супутньої перинатальної патології.

МАТЕРІАЛИ ТА МЕТОДИ. Проведено когортне дослідження типу «випадок-контроль» із комплексним клінікопараклінічним обстеженням 65 доношених новонароджених, у яких на тлі перинатальної патології спостерігалися порушення функціонального стану нирок (I група), та 30 дітей $з$ тяжкими формами перинатальної патології, на тлі якої було діагностовано ГПН (II група). Дослідження виконано на базі відділення інтенсивної терапії новонароджених (BITH) Міської комунальної медичної установи «Клінічний пологовий будинок № 2» (м. Чернівці) за період 2013-2015 рр. Дітей обстежено після отримання письмової згоди батьків з дотриманням основних етичних принципів проведення наукових медичних досліджень та схвалення програми дослідження Комісією з питань біомедичної етики Буковинського державного медичного університету.

Встановлення тяжкості перинатальної патології проведено 3 використанням шкали гострої фрізіології новонароджених - Score for Neonatal Acute Physiology Perinatal Extension (SNAPPE) [9]. Критерієм відбору до груп дослідження була максимальна оцінка за шкалою SNAPPE під час перебування у BITH - більше 15 балів. Діагностику ГПН у новонароджених здійснено згідно з рекомендаціями міжнародної групи експертів Kidney Disease: Improving Global Outcomes з модифрікацією J. G. Jetton ta D. J. Askenazi [3].
Для визначення внеску фракторів ризику у розвиток ГПН у новонароджених дітей вивчено якісні та кількісні характеристики особливостей стану здоров'я матерів, перебігу антенатального періоду розвитку та періоду пологів, клінічних проявів тяжкої перинатальної патології у ранній неонатальний період. Для вивчення характеру соматичної та акушерської патології у матерів дітей груп обстеження, а також особливостей перебігу гестаційного періоду та пологів проведено ретроспективний аналіз обмінних карт вагітних (Ф № 113/o) та історій пологів (Ф № 096/о). Клінічне обстеження новонароджених здійснено за загальноприйнятою методикою з оцінкою гострої постнатальної адаптації за шкалою Апгар та визначенням клінічних симптомів тяжкої перинатальної патології, проявів ниркової диссрункції. Стан ренальних фуннццій оцінювали шляхом визначення у сироватці крові рівнів креатиніну та сечовини з використанням реактивів фрірми ТОВ НВП «Філісіт-діагностика» (м. Дніпропетровськ). Швидкість клубочкової фрільтрації (ШКФ) розраховували за модифікованою формулою Шварца: ШКФ $($ мл/хв/1,73м²) $=\mathrm{k} \cdot \mathrm{d}(\mathrm{cm}) /$ креатинін сироватки (мкмоль/л) · 0,0113, де k=0,45 для доношених новонароджених [10].

Для статистичного аналізу результатів використано програми Statistica (StatSoft Inc., USA, 2010) та MedCalc Software Version 16.1. За умов нормального розподілу величин (критерій Шапіро-Уілка > 0,05) застосовано параметричні методи статистики з розрахунком середньої арифрметичної величини (М) та похибки репрезентативності середньої величини $(\mathrm{m})$. Порівняння кількісних показників з нормальним розподілом проведено з використанням t-критерію Стьюдента. Порівняння відносних величин здійснено за допомогою точного критерію Фішера. Різницю параметрів вважали статистично значущою при р<0,05. Для визначення зв'язку між фракторами ризику та розвитком ГПН у критично хворих новонароджених проводили логістичний регресійний аналіз із розрахунком відношення шансів (ВШ) та $95 \%$ довірчого інтервалу (95 \% ДI). Результати вважали статистично значимими, якщо значення довірчого інтервалу не містили «1».

РЕЗУЛЬТАТИ ДОСЛІДЖЕННЯ ТА ЇХ ОБГОВОРЕНня. Оцінка антропометричних та гендерних показників новонароджених показала, що групи обстеження $€$ зіставними. Так, середня маса тіла при народженні у дітей I групи склала $(3353,0 \pm 496,03)$ г; у новонароджених |I групи - $(3411,0 \pm 409,0)$ г, р>0,05. Середня довжина тіла дітей становила, відповідно, $(53,3 \pm 2,53)$ та $(53,5 \pm 2,27) \mathrm{cm}$, p>0,05. Хлопчики превалювали в усіх групах обстеження: відповідно, 44 дитини (67,7 \% випадків) та 19 дітей (70,0 \% випадків). У нашому дослідженні не відмічено статистично значимої різниці між групами дослідження за антропометричними показниками й гендерними ознаками та, відповідно, статистично значимих асоціацій із формуванням ГПН у доношених новонароджених.

Діагноз ГПН у пацієнтів ВІТН було встановлено відповідно до існуючих рекомендацій [12] 3 урахуванням двох критеріїв: підвищення рівня креатиніну сироватки крові більш ніж на 26,6 мкмоль/л протягом послідовних двох досліджень, проведених через 48 год, та/або рівня погодинного діурезу менше 0,5 мл/кг/год протягом 6 год [12]. У 10 дітей II групи (33,3 \% випадків) діагноз встановлено на основі відповідної динаміки рівня креатиніну, в 7 дітей (23,4 \% випадків) - динаміки діурезу та у 13 дітей 
(43,3 \% випадків) - поєднання обох критеріїв. Таким чином, результати нашого дослідження підтверджують дані інших авторів про достатньо високу частоту розвитку неолігоуричного типу ГПН у новонароджених дітей, що часто призводить до пізньої діагностики даного стану, неадекватної корекції лікування та високої смертності у ранній неонатальний період $[1,3,11]$.

3 метою встановлення ймовірних пренатальних факторів ризику формування ГПН у доношених новонароджених проведено ретроспективний аналіз даних обмінних карт та історій пологів у матерів з урахуванням груп порівняння (табл.).

Аналіз представлених пренатальних фракторів не встановив статистично значимих відмінностей щодо місця проживання, паритету вагітності та пологів, а також вікових характеристик матерів дітей груп дослідження.
Порівняння частоти виявлення специфічної соматичної патології та пренатальних ускладнень між I та II групами надало змогу встановити ймовірні фрактори ризику формування ГПН у критично хворих новонароджених. Так, шанси мати ГПН при наявності в анамнезі у матері захворювань сечовидільної системи становлять 2,68 (95 \% ДІ 1,080-6,680, p<0,05); обтяженого акушерського анамнезу - 2,76 (95 \% ДІ 1,129-6,764, p<0,05). Отримані результати підтверджують дані інших авторів про тісний зв'язок між патологічними змінами сечовидільної системи у матерів та ймовірністю розвитку нефропатій в їх дітей, що пов'язано як із загальними негативними дисметаболічними змінами у системі мати-плацента-плід, так й існуванням «генетичної пам'яті» [12].

Звертає увагу те, що на фрормування тяжкої перинатальної патології у новонароджених суттєво впливали

Таблиця. Особливості анамнезу, соматичної та гінекологічної патології, перебігу вагітності та пологів у матерів дітей груп порівняння, $\mathrm{n}$ ( \%)

\begin{tabular}{|c|c|c|}
\hline Показник & I група $(n=65)$ & II група $(n=30)$ \\
\hline \multicolumn{3}{|l|}{ Дані анамнезу } \\
\hline Міські мешканки & $34(52,3)$ & $17(56,7)$ \\
\hline Сільські мешканки & $31(47,7)$ & $13(43,3)$ \\
\hline Паритет вагітності 1 & $35(53,8)$ & $13(43,3)$ \\
\hline Паритет вагітності $\geq 2$ & $30(46,2)$ & $17(56,7)$ \\
\hline Паритет пологів 1 & $37(56,9)$ & $19(63,3)$ \\
\hline Паритет пологів $\geq 2$ & $28(43,1)$ & $11(36,7)$ \\
\hline Вік матері $\leq 17$ років & $1(1,5)$ & - \\
\hline Вік матері $\geq 35$ років & $7(10,8)$ & $7(23,3)$ \\
\hline \multicolumn{3}{|l|}{ Соматична патологія } \\
\hline Патологія сечовидільної системи & $16(24,6)$ & $14(46,7)^{\star}$ \\
\hline Патологія травної системи & $7(10,8)$ & $7(23,3)$ \\
\hline Патологія дихальної системи & $1(1,5)$ & - \\
\hline Патологія серцево-судинної системи & $16(24,6)$ & $3(10)$ \\
\hline Патологія ендокринної системи & $21(32,3)$ & $10(33,3)$ \\
\hline Опасистість & $7(10,8)$ & $3(10)$ \\
\hline \multicolumn{3}{|l|}{ Гінекологічна патологія } \\
\hline Вагініт/кольпіт & $12(18,5)$ & $3(10)$ \\
\hline Обтяжений акушерський анамнез & $25(38,4)$ & $18(60)^{*}$ \\
\hline \multicolumn{3}{|l|}{ Перебіг даної вагітності } \\
\hline Загроза самовільного викидня та передчасних пологів & $40(61,5)$ & $23(76,7)$ \\
\hline Прееклампсія & $7(10,8)$ & $1(3,3)$ \\
\hline Анемія вагітних & $32(49,2)$ & $13(43,3)$ \\
\hline Багатоводдя & $5(7,7)$ & $2(6,7)$ \\
\hline \multicolumn{3}{|l|}{ Перебіг даних пологів } \\
\hline Ургентний кесарів розтин & $19(29,2)$ & $10(33,3)$ \\
\hline Дистрес плода у пологах, що загрожує життю & $24(36,9)$ & $15(50)$ \\
\hline Слабкість пологової діяльності & $6(9,2)$ & $3(10)$ \\
\hline Дискоординація пологової діяльності & $3(4,6)$ & $1(3,3)$ \\
\hline Передчасний розрив навколоплідних оболонок & $10(15,4)$ & $8(26,7)$ \\
\hline Індукція пологів & $4(6,2)$ & $1(3,3)$ \\
\hline Вакуум-екстракція плода & $7(10,8)$ & $1(3,3)$ \\
\hline Вихідні акушерські клещата & - & $2(6,7)$ \\
\hline Епідуральна анестезія & $1(1,5)$ & $2(6,7)$ \\
\hline Обвиття пуповиною & $6(9,2)$ & $6(20)$ \\
\hline Меконіальні навколоплідні води & $27(41,5)$ & $13(43,3)$ \\
\hline
\end{tabular}

Примітка. * - рівень значущості різниці показників між групами порівняння при $p<0,05$. 
несприятливі фрактори інтранатального періоду, про що свідчила значна частота дистресу плода в пологах, що загрожує життю, наявності меконіальних навколоплідних вод та проведень ургентного кесаревого розтину як у I, так і в II групі дослідження. При цьому статистично значимої різниці між групами порівняння щодо частоти представлених патологічних факторів та, відповідно, асоціацій із срормуванням ГПН у новонароджених не встановлено.

Результати клінічного обстеження дітей при народженні показали наявність порушень процесів гострої адаптації приблизно у половини новонароджених дітей 3 тяжкими порушеннями періоду постнатальної адаптації. Так, на 1-й хвилині життя оцінка за шкалою Апгар «0-3» бали була відмічена у 6 дітей (9,2\% випадків) I групи та у 5 дітей (16,7 \% випадків) II групи, р>0,05; «4-6 балів» - відповідно, у 35 дітей (56,0 \% випадків) та у 12 дітей (40,0 \% випадків), р>0,05. На 5-й хвилині життя оцінка за шкалою Апгар «0-3» бали була відзначена у 4 дітей (6,2 \% випадків) I групи та у 5 дітей (16,7 \% випадків) II групи, р<0,05; «4-6 балів» - відповідно, у 29 дітей (44,6\% випадків) та у 7 дітей (23,3 \% випадків), р>0,05. У ході проведення регресійного логістичного аналізу встановлено статистично значимі асоціації між оцінкою за шкалою Апгар менше 3 балів наприкінці 5-ї хвилини життя та фрормуванням ГПН у новонароджених - ВШ 5,08 (95 \% ДІ 1,215-21,263, p<0,05).

Необхідно відмітити, що 23 дитини (35,3 \% випадків) I групи та 12 дітей (40,0 \% випадків) II групи народилися із задовільною оцінкою за шкалою Апгар, але їх стан погіршився впродовж перших годин життя за рахунок поглиблення соматичної та/або неврологічної симптоматики.

Структура основної перинатальної патології у новонароджених дітей груп порівняння була представлена ассріксією тяжкого ступеня у 3,1 \% випадків I групи та у $6,7 \%$ випадків ІІБ групи ( $>0,05)$, асфріксією помірного ступеня - відповідно, у 16,9 та 10,0 \% випадків ( $p>0,05)$, синдромом аспірації меконію - відповідно, у 6,2 та 3,3 \% випадків ( $>>0,05)$, поєднанням ассріксії тяжкого ступеня та аспірації меконію - відповідно, у 3,1 та 6,7 \% випадків ( $>>0,05)$, поєднанням асфріксії помірного ступеня та аспірації меконію - відповідно, у 18,5 та 10,0 \% випадків $(p<0,05)$, набряком мозку - відповідно, у 24,6 та 26,7 \% випадків ( $>>0,05)$, неонатальною енцефалопатією - відповідно, у 23,1 та 26,7 \% випадків (р>0,05), синдромом дихальних розладів - відповідно, у 4,6 та 10,0 \% випадків $(p<0,05)$.

Незважаючи на відсутність статистично значимої різниці щодо частоти нозологічних форм захворювань між групами порівняння, у доношених дітей із ГПН встановлено більш виражений ступінь тяжкості перинатальної патології, зокрема клінічні прояви поліорганного пошкодження. Так, перебіг основного захворювання був ускладнений розвитком артеріальної гіпотензії у 32,3 \% випадків I групи та у 66,7 \% випадків II групи $(p<0,05)$, розладами мікроциркуляції, які характеризувалися позитивним симптомом «білої плями», - відповідно, у 23,1 та $70,0 \%$ випадків $(p<0,05)$, гастроінтестинальними розладами - відповідно, у 36,9 та 66,7 \% випадків ( $><0,05)$, геморагічним синдромом - відповідно, у 7,7 та $30 \%$ випадків $(p<0,05)$. Порушення фрункціонування нервової системи у вигляді судомного синдрому спостерігалося у 10,8 \% випадків I групи та 40,0 \% випадків II групи ( $<<0,05)$, синдрому пригнічення - відповідно, у 55,4 та $56,7$ \% випадків ( $>>0,05)$, синдрому підвищеної нервоворесрлекторної збудливості - відповідно, у 24,6 та 26,7 \% випадків ( $>>0,05)$, синдрому вегетовісцеральних розладів - відповідно, у 52,3 та 33,3 \% випадків (p>0,05). Прояви дихальних розладів тяжкого ступеня діагностовано у 100 \% випадків обох груп дослідження.

Статистичний аналіз виявив найбільш значущі асоціації між розвитком ГПН у новонароджених та синдромом артеріальної гіпотензії (ВШ 4,19 при 95 \% ДІ 1,67-10,516, $\mathrm{p}<0,05)$, позитивним симптомом «білої плями» (ВШ 7,78 при $95 \%$ ДІ 2,946-20,537, р<0,05), судомним синдромом (ВШ 5,52 при $95 \%$ ДІ 1,891-16,132, р<0,05), геморагічним синдромом (ВШ 5,14 при 95 \% ДІ 1,548-17,09, $\mathrm{p}<0,05)$ та харчовою інтолерантністю (ВШ 3,42 при $95 \%$ ДІ 1,347-8,497, p<0,05). Це підтверджує дані літератури щодо поліорганності гіпоксичного пошкодження організму новонароджених за умов тяжкої перинатальної патології, зокрема втрати механізмів авторегуляції ренальної гемодинаміки та їх прямої залежності від центральних і серцевих механізмів регуляції $[1,3]$. На нашу думку, представлені статистично значимі асоціації підтверджують доцільність проведення своєчасного комплексного обстеження критично хворих новонароджених щодо прогнозування розвитку поліорганної невідповідності у контексті цілого організму, зокрема ГПН, для проведення своєчасної корекції терапевтичних втручань.

Одним із клінічних проявів ренальних дисорункцій $€$ набряковий синдром, який відмічали у 7 критично хворих дітей без ознак ГПН (10,8 \% випадків) та у 9 новонароджених із проявами ГПН (30 \% випадків), р<0,05. Об'єктивна оцінка маси тіла дітей зазначених груп показала, що впродовж перебування у ВІТН у більшості новонароджених превалювала позитивна динаміка маси тіла, яка була статистично більш значимою в дітей із проявами ГПН. Так, наприкінці першої доби середня прибавка маси тіла від початкової маси у новонароджених дітей I групи склала $(1,8 \pm 0,09) \%$, у дітей II групи - $(2,8 \pm 0,11) \%(p<0,05)$; другої доби - відповідно, $(1,89 \pm 0,09)$ та $(3,95 \pm 0,19) \%(p<0,05)$; третьої доби - відповідно, $(2,19 \pm 0,11)$ та $(4,34 \pm 0,22) \%$ $(p<0,05)$; четвертої доби - відповідно, $(3,54 \pm 0,16)$ та $(4,72 \pm 0,24) \%(p<0,05)$. Суттєве добове зростання маси тіла понад 5 \% наприкінці другої доби життя, що випереджало суттєве збільшення рівня біохімічних маркерів ГПН, спостерігалося статистично значимо частіше у дітей I групи порівняно 3 дітьми II групи (відповідно, у 3,1 та 23,3 \% випадків, $p<0,05)$.

У дослідженні встановлено статистично значимі асоціації між фрормуванням ГПН у дітей із тяжкою перинатальною патологією та клінічними ознаками, які виникли ще до суттєвого підвищення рівня сироваткового креатиніну та/або зменшення погодинного діурезу: набряковим синдромом (ВШ 3,55 при 95 \% ДІ 1,174-10,740, р<0,05) та збільшенням маси тіла $\geq 5 \%$ від початкової на 2-гу добу життя (ВШ 8,68 при ДІ 1,675-44,912, p<0,05).

Таким чином, формування ГПН у доношених новонароджених із тяжкою перинатальною патологією має мультифракторний характер, тісно пов'язане з наявністю в матері патології сечовидільної системи та обтяженого акушерського анамнезу, а також низькою оцінкою за шкалою Апгар наприкінці 5-ї хвилини життя, проявами 
синдрому поліорганної невідповідності (артеріальною гіпотензією, порушеннями мікроциркуляції, судомним та геморагічним синдромами, харчовою інтолерантністю) та ренальної диссрункції (набряковим синдромом та збільшенням маси тіла $\geq 5$ \% від початкової на 2-гу добу життя).

ВИСНОВКИ. 1. Статистично значимими пренатальними фракторами ризику формування ГПН у доношених дітей є патологія сечовидільної системи в матері (ВШ 2,68; 95 \% ДІ 1,080-6,680) та обтяжений акушерський анамнез (ВШ 2,76; 95 \% ДІ 1,129-6,764).

2. Розвиток ГПН у дітей із тяжкою перинатальною патологією статистично значимо пов'язаний з оцінкою за шкалою Апгар менше 3 балів наприкінці 5-ї хвилини життя (ВШ 5,08; 95 \% ДІ 1,215-21,263) та клінічними проявами поліорганного пошкодження: позитивним симптомом «білої плями» (ВШ 7,78; 95 \% ДІ 2,946-20,537), синдромом артеріальної гіпотензії (ВШ 4,19; 95 \% ДІ 1,67-10,516), судомним синдромом (ВШ 5,52; $95 \%$ ДІ 1,891-16,132), геморагічним синдромом (ВШ 5,14; $95 \%$ ДІ 1,548-17,09), харчовою інтолерантністю (ВШ 3,42; $95 \%$ ДІ 1,347-8,497).

3. Клінічними симптомами, які пов'язані з високою ймовірністю формування ГПН та випереджають суттєві зміни біохімічних маркерів, є збільшення маси тіла $\geq 5$ \% від початкової на 2-гу добу життя (ВШ 8,68; ДІ 1,675-44,912) та набряковий синдром (ВШ 3,55; 95 \% ДІ 1,174-10,740).

ПЕРСПЕКТИВИ ПОДАЛЬШИХ ДОСЛІДЖЕНЬ СПрЯмовані на пошук лабораторних критеріїв доклінічної діагностики для прогнозування розвитку ГПН при тяжких фрормах перинатальної патології у доношених новонароджених з метою проведення своєчасної корекції лікувальних заходів.

\section{СПИСОК ЛІТЕРАТУРИ}

1. Багдасарова І. В. Хронічна хвороба нирок та стан замісної ниркової терапії в Україні [Електронний ресурс] / І. В. Багдасарова, С. П. Фоміна // Український журнал несрології та діалізу. - 2015. - № 1 (45). - Режим доступу : http:// ukrjnd.com.ua/files/file/archive/n45/Bagdasarova.pdf.

2. Лобода А. М. Поширеність ішемічної нефропатії у новонароджених / А. М. Лобода // Вісник СумдУ. Серія «Медицина». - 2011. - № 2. - С.128-133.

3. Bezerra C. T. Defining reduced urine output in neonatal ICU: importance formortality and acute kidney injury classification / C. T. Bezerra, L. C. Vaz Cunha, A. B. Libłorio // Nephrology Dialysis Transplantation.-2013.- Vol.28, № 4.-P.901-909.

4. Durkan AM. Acute kidney injury post neonatal asphyxia / AM. Durkan, RT. Alexander // J. Pediatr.- 2011.- Vol.158.P. 29-33.

5. Epidemiology of cardiac surgery-associated acute kidney injury in neonates: a retrospective study / A. Alabbas, A. Campbell, P. Skippen [et al.] // Pediatric Nephrology.-2013.Vol.28, №7.-P.1127-1134.

6. Etiology and outcome of acute kidney injury in children / A. Duzova, A. Bakkaloglu, M. Kalyoncu [et al.] // Pediatr. Nephrol.- 2010.-Vol. 25.-P.1453-61.
7. Hahn H. Genetics of kidney development: patho $\neg$ genesis of renal anomalies / H. Hahn // Korean J. Pediatr.- 2010.- Vol.53 (7). - P. 729-734.

8. Incidence and Risk Factors of Acute Kidney Injury among the Critically III Neonates / A.A. El-Badawy, S. Makar, A.-R. A. Abdel-Razek [et al.] // Saudi J. Kidney Dis. Transpl.-2015.-26 (3).-P.549-555.

9. Incidence of Acute Kidney Injury in the Neonatal Intensive Care Unit / D. Youssef, H. Abd-Elrahman, M. Shehab [et al.] // Saudi J. Kidney Dis. Transpl.-2015.-26 (1).-P.67-72.

10. Neonatal Acute Kidney Injury [Електронний ресурc] / David T. Selewski, Jennifer R. Charlton, Jennifer G. Jetton [et al.] // Pediatrics.-2015.-Vol.136, №3.-P. 463-473.- Режим доступу : http://pediatrics.aappublications.org/content/early/2015/07/08/ peds.2014-3819

11. Risk factors for and outcomes of acute kidney injury in neonates undergoing complex cardiac surgery / C. J. Morgan, M. Zappitelli, C. M. Robertson [et al.] // Journal of Pediatrics.-2013.- Vol.162, №1.-P.120.e1-127.e1.

12. Score for Neonatal Acute Physiology: a physiologic severity index for neonatal intensive care / D. K. Richardson, J. E. Gray, M.C. McCormick [et al.] // Pediatrics.- 1993.Vol. 91(3).-P.617-623.

Отримано 09.02.16 